\title{
Analisis Pemasaran Agroindustri Kerupuk Ubi Kayu di Desa Pulau Aro Kecamatan Kuantan Tengah Kabupaten Kuantan Singingi
}

\author{
Jamalludin*, Chezy WM. Vermila, Andi Alatas \\ Fakultas Pertanian, Universitas Islam Kuantan Singingi \\ * fit_jamal@yahoo.com
}

\begin{abstract}
Abstrak. Tujuan dari penelitian ini untuk menganalisis jumlah produksi, harga jual pengusaha kerupuk ubi kayu, dan pemasaran dari aspek saluran pemasaran. Pengambilan sampel untuk pengusaha agroindustri kerupuk ubi kayau diambil secara Proposif sebanyak 30. Sedangnkan pedagang pengumpul, yang diambil masih aktif melakukan kegiatan pemasaran kerupuk ubi kayu selama 6 tahun terakhir. Hasil penelitian jumlah produksi pengusaha kerupuk ubi kayu berkisar 145/Kg/bulan. Dengan pendapatan rata-rata per bulan sebesar Rp. 3.195.133,- dengan harga Rp.20.000,sampai Rp.22.000,- Saluran pemasaran I kerupuk ubi kayu dipasarkan lasung dirumah, konsumen yang langsung datang kerumah membeli kerupuk ubi kayu dalam bentuk mentah. Saluran Pemasaran II kerupuk ubi kayu dalam bentuk mentah di pasarkan langsung dari rumah maupun ke tempat pasar-pasar tradisional yang terdekat ke pedagang pengumpul yang ada di pasar. Dalam memasarkan kerupuk ubi kayu, pengusaha hanya mengeluarkan biaya transportasi dari rumah kepasar sebesar Rp. 2000,- adapun jarak rumah dengan pasar berkisar $3 \mathrm{~km}$ dan ada juga kerupuk ubi kayu dijemput langsung oleh pedagang pengumpul ke rumah, pedagang pengumpul mengeluarkan biaya operasional, ratarata Rp. 23.000,-/bulan atau sebesar Rp. 260,-/kg. Margin pemasaran kerupuk ubi kayu di peroleh sebesar Rp. 2.400,$/ \mathrm{kg}$. Margin pemasaran saluran pemasaran II yang dikelaurkan oleh pedagang pengumpul sebesar Rp. 3.000,-/kg. dengan harga jual 24.400,-/kg. Efisiensi pemasaran pada saluran pemasaran I adalah $0 \%$, lebih kecil nilai efisiensi pemasaran pada saluran pemasaran II adalah 1,07\%. Hal ini berarti saluran pemasaran I lebih efisien dari pada saluran pemasaran II. Pada saluran pemasaran I marjin pemasarannya adalah Rp. 0,-.
\end{abstract}

Kata Kunci: kerupuk ubi kayu, produksi, harga penjualan, analisis pemasaran

\section{PENDAHULUAN}

Perkembangan perekonomian Indonesia dipengaruhi oleh sektor pertanian dan industri. Industrialisasi pertanian dapat dikembangkan melalui sektor agroindustri yang merupakan perpaduan sektor pertanian dan industri yang saling mendukung dalam kegiatan memperkuat perekonomian rakyat sehingga berperan dalam hal terciptanya kesempatan kerja, diversifikasi produk pertanian, memberikan nilai tambah dan meningkatkan pendapatan masyarakat. Pengembangan agroindustri sebagai langkah industrialisasi pertanian merupakan pilihan strategi yang tepat, karena tidak hanya menciptakan kondisi yang saling mendukung antara kekuatan industri maju dengan pertanian yang tangguh, tetapi juga membentuk keterpaduan sektor industri pertanian yang mampu memberikan perubahan melalui penyerapan tenaga kerja, peningkatan dan perbaikan pembagian pendapatan, peningkatan perolehan devisa Negara dan mampu mendorong munculnya industri baru (Hanani, 2003).

Agroindustri adalah industri yang mengolah hasil pertanian sebagai bahan baku atau produk akhir yang dapat meningkatkan nilai tambah atas komoditas pertanian sekaligus merubah pertanian tradisional menjadi modern, akan dapat meningkatkan pendapatan dan lapangan kerja di pedesaan yang tentunya menurut skala usaha tani yang ekonomis serta efesien (Soekartawi, 2000).

Untuk mencapai tujuan tersebut perlu adanya penanganan yang sistematis mulai dari subsistem penyediaan bahan baku sampai subsistem proses produksinya. Hal ini dapat diwujudkan melalui kegiatan agroindustri. Menekan pentingnya sektor industri di pedesaan ini mengingat masih ada sekitar 50\% tenaga kerja yang bekerja di sektor pertanian, dan lainnya tinggal di pedesaan sebagai petani. Dengan demikian 
adanya agroindustri secara keseluruhan diharapkan khususnya dapat menyerap tenaga kerja petani di pedesaan serta meningkatkan pangsa pasar dan ekspor, meningkatkan poduk domestik bruto, serta sebagai persiapan menuju industri Negara baru (Baharsjah, 1992).

Ubi kayu merupakan salah satu tanaman pangan yang memiliki banyak kelebihan. Misalnya saja pada saat cadangan makanan (padi-padian) mengalami kekurangan, ubi kayu masih dapat diandalkan sebagai sumber bahan pengganti karena ubi kayu merupakan tanaman yang tahan terhadap kekurangan air sehingga masih dapat di produksi di lahan kritis sekalipun dan cara penanaman ubi kayu yang mudah. Tujuan pengolahan ubi kayu itu sendiri adalah untuk meningkatkan keawetan ubi kayu sehingga layak untuk dikonsumsi dan memanfaatkan agar memperoleh nilai jual yang tinggi dipasaran.

Riau memproduksi sebesar 103.599 ton dengan luas panen 3.578 ha. Kabupaten Kuantan Singingi merupakan salah satu Kabupaten di Riau yang memproduksi ubi kayu sebanyak 2.738,20 ton dengan luas panen 273 ha. Bahwa hasil produksi ubi kayu di Kabupaten Kuantan Singingi sebanyak 2738,20 ton dengan luas panen 273 ha. Ini menunjukkan bahwa produksi ubi kayu di Kabupaten Kuantan Singingi cukup banyak, dan Kuantan Mudik adalah Kecamatan yang memproduksi ubi kayu terbanyak yakni sebanyak 718,20 ton dengan luas panen 72 ha (Dinas Tanaman Pangan Kuantan Singingi, 2015).

Untuk memanfaatkan ubi kayu, Kabupaten Kuantan Singingi dapat mengelola ubi kayu menjadi suatu produk. Terdapat beberapa Usaha Mikro, Kecil dan Menengah (UMKM) di Kabupaten Kuantan Singingi yang bergerak dalam sektor Industri Pengolahan. Kabupaten Kuantan Singingi terdapat 536 jumlah UMKM sektor industri pengolahan dan Kecamatan Kuantan Tengah memiliki 238 UMKM Sektor Industri Pengolahan (Diskopindag, 2017).

Berdasarkan survei yang telah dilakukan terdapat Industri Pengolahan Kerupuk Ubi Kayu yang masih aktif dan terdapat di Desa Pulau Aro. Desa Pulau Aro merupakan desa yang terdapat di Kecamatan Kuantan Tengah yang banyak terdapat Usaha Agroindustri Kerupuk Ubi Kayu skala rumahan yakni terdapat sebanyak 30 Agroindustri yang memproduksi kerupuk ubi kayu.

Industri Pengolahan Kerupuk Ubi Kayu di Desa Pulau Aro Kecamatan Kuantan Tengah Kabupaten Kuantan Singingi untuk usaha kerupuk ubi dalam proses pembuatan dan kegiatan pemasaran bukan sekedar menjual barang, melainkan segala aktivitas yang berhubungan dengan arus barang sejak dari tangan produsen sampai ke tangan konsumen akhir, akan meningkat seiring dengan meningkatnya jumlah penduduk dan permintaan kerupuk ubi. Hal ini menunjukkan bahwa adanya potensi pemasaran pada kerupuk ubi.

Permasalahan yang terjadi dalam pemasaran kerupuk ubi kayu berdampak pada keuntungan yang diperoleh agroindustri kerupuk ubi kayu maupun lembaga pemasaran. Oleh karena itu, diperlukan adanya sistem pemasaran yang tetap dalam memasarkan kerupuk ubi kayu hingga sampai ke konsumen. Selain itu, pemasaran yang diterapkan harus efisien sehingga dapat memberikan keuntungan yang adil kepada agroindustri kerupuk ubi kayu keuntungan maupun lembaga pemasaran. Untuk mengetahui efisien tidaknya suatu pemasaran digunakan indikator nilai persentase marjin pemasaran.

Selain itu mutu kerupuk para agroindustri kerupuk ubi kayu yang relatif rendah dan di jual dalam bentuk mentah, sehingga membuat konsumen harus memasak atau mengoreng baru bisa di konsumsi. Akibatnya para agroindustri kerupuk ubi kayu menjual langsung dan ke lembaga perantara.

\section{METODE}

Penelitian ini dilaksanakan dengan menggunakan metode survei yang dilaksanakan di Desa Pulau Aro Kecamatan Kuantan Tengah Kabupaten Kuantan Singingi. Pemilihan lokasi penelitian ini didasarkan pada pertimbangan bahwa Penetapan daerah penelitian ini dilakukan secara sengaja dengan pertimbangan bahwa lokasi tersebut merupakan sentaral produksi kerupuk ubi kayu. Penelitian ini telah dilaksanakan dari bulan April sampai bulan Juli 2018.

Pengambilan sampel untuk pengusaha agroindustri kerupuk ubi kayau diambil secara Proposif di Kecamatan Kuantan Tengah Karna memiliki Jumlah UMKM Terbanyak dibanding Kecamatan Lain di Kabupaten Kuantan Singingi. Penulis memilih Desa Pulau Aro Karena Agroindustri Kerupuk Ubi kayu Banyak terdapat di Desa Pulau Aro. Sampel dalam penelitian ini adalah pemilik dan tenaga kerja Agroindustri Kerupuk Ubi Kayu. Berdasarkan hasil survei, diketahui usaha agroindustri kerupuk ubi kayu aktif berjumlah 30 orang.

Sedangkan untuk pedagang yang mengusahakan jual beli kerupuk ubi kayu di Desa Pulau Aro Kecamatan Kuantan Tengah Kabupaten Kuantan Singingi yang diambil untuk sampel, terdiri dari 5 orang pedagang 
pengumpul, dengan pertimbangan bahwa sampel yang diambil masih aktif melakukan kegiatan pemasaran kerupuk ubi kayu selama 6 tahun terakhir (2012-2018).

Analisis yang digunakan dalam penelitian ini adalah analisis diskriptif dan analisis kuantitatif.

\section{Jumlah Produksi Kerupuk Ubi Kayu}

Produksi merupakan jumlah output yang dihasilkan dari proses usaha (kerupuk ubi kayu) dalam kegiatan usaha yang dinyatakan dalam satuan $\mathrm{kg}$. Jumlah produksi adalah hasil dari usaha kerupuk ubi kayu dalam bentuk mentah, dihitung dalam ukuran $\mathrm{kg}$ dan dibedakan mutu serta ukuran produk. Untuk menghitung jumlah produksi adalah hasil kerupuk ubi kayu perhari dikumpulkan satu kali seminggu dan dikalikan empat minggu untuk mencari produksi perbulan.

\section{Harga Penjualan}

Harga jual yang diperhitungkan dalam penelitian ini adalah harga pasar yang diterima pengusaha dari hasil penjualan kerupuk ubi kayu yang dinyatakan dalam bentuk Rp/kg.

\section{Analisis Pemasaran}

\section{Saluran Pemasaran}

Saluran pemasaran dianalisis secara deskriptif kualitatif, dimana untuk mengetahui saluran pemasaran kerupuk ubi kayu di Desa Pulau Aro Kecamatan Kuantan Tengah Kabupaten Kuantan Singingi. dengan cara mengikuti aliran produksi kerupuk ubi kayu dari pengusaha sampai ke konsumen akhir menjelaskan apa adanya kejadian di lapangan dengan kalimat-kalimat penjelasan secara umum yang bertujuan untuk mendapatkan informasi tentang berbagai saluran pemasaran secara langsung dan saluran pemasaran melalui perantara. Jika pemasaran dilakukan secara langsung, maka konsumen membayar produk dari harga yang ditawarkan pengusaha. Sedangkan pemasaran yang melalui perantara akan melibatkan pedagang lain.

\section{a. Lembaga Pemasaran}

Lembaga pemasaran dianalisis secara deskriptif kualitatif, dimana untuk mengetahui lembaga pemasaran seperti badan-badan yang menyelengarakan kegiatan pemasaran seperti: bentuk lembaga, tujuan, kerja lembaga, rantai pemasaran dan proses pemasaran.

\section{b. Fungsi-Fungsi Lembaga Pemasaran}

Fungsi-fungsi pemasaran dianalisis secara deskriptif kualitatif, dimana untuk mengetahui dari fungsi lembaga pemasaran yang dilakukan, adapun dilakukan fungsi lembaga pemasaran ini bertujuan untuk mendapatkan informasi tentang berbagai fungsi-fungsi pemasaran yang ada seperti: penjualan, pembelian, pengangkutan, penyimpanan, standarisasi, pembiayaan, penanggungan resiko, dan informasi pasar.

\section{c. Biaya pemasaran}

Menghitung besarnya biaya pemasaran dapat menggunakan rumus menurut Soekartawi (1993) sebagai berikut:

$$
\begin{aligned}
& \mathrm{Bp}=\mathrm{Bi}+\mathrm{Bn} . \ldots \ldots \ldots \ldots \\
& \mathrm{Bp}=\mathrm{B} 1+\mathrm{B} 2+\mathrm{B} 3+\mathrm{B} 4
\end{aligned}
$$

$$
\begin{aligned}
& \text { Keterangan: } \\
& \mathrm{BP}=\text { Biaya pemasaran }(\mathrm{Rp} / \mathrm{kg}) \\
& \mathrm{Bi}=\text { Biaya ke } \mathrm{i}(\mathrm{Rp} / \mathrm{kg}) \\
& \mathrm{Bn}=\text { Biaya } \mathrm{ke} \mathrm{n}(\mathrm{Rp} / \mathrm{kg}) \\
& \mathrm{B} 1=\text { Biaya pembungkusan }(\mathrm{Rp} / \mathrm{kg}) \\
& \mathrm{B} 2=\text { Biaya transportasi }(\mathrm{Rp} / \mathrm{kg}) \\
& \mathrm{B} 3=\text { Biaya tempat }(\mathrm{Rp} / \mathrm{kg}) \\
& \mathrm{B} 4=\text { Biaya bongkar muat }(\mathrm{Rp} / \mathrm{kg})
\end{aligned}
$$

\section{d. Margin Pemasaran}

Untuk menghitung margin pemasaran digunakan Rumus (Hanafiah dan Saefuddin 1986), yaitu:

$$
\mathrm{M}=\mathrm{Hk}-\mathrm{Hp} \text {. }
$$

Dimana: 
$\mathrm{M}=$ Margin pemasaran $(\mathrm{Rp} / \mathrm{kg})$

$\mathrm{Hk}=$ Harga yang dibayarkan konsumen akhir $(\mathrm{Rp} / \mathrm{kg})$

$\mathrm{Hp}=$ Harga yang diterima distributor $(\mathrm{Rp} / \mathrm{kg})$

\section{e. Keuntungan Pemasaran}

Menurut Soekartawi (2002), merupakan selisih anatara margin pemasaran dengan biaya pemasaran atau dirumuskan:

$$
\pi=\mathrm{M}-\mathrm{B}
$$

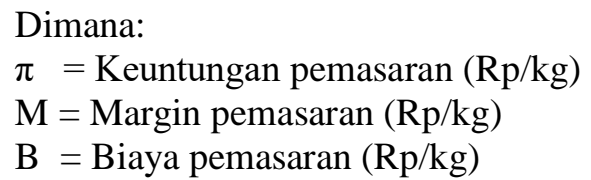

\section{g. Efisiensi Pemasaran}

Untuk menghitung efisiensi pemasaran, secara umumnya dapat digunakan rumus menurut Soekartawi (1993):

$$
\mathrm{EP}=\mathrm{TB} \times 100 \% / \mathrm{TNP}
$$

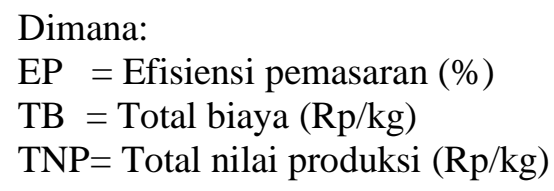

Dengan ketentuansemakin rendah rasio total biaya dengan total nilai produk maka sistem pemsaran semakin efisien dan apabila semakin tinggi ratio total biaya dengan total nilai produk maka sistem pemasaran tidak efisien.

\section{HASIL DAN PEMBAHASAN}

\section{Produksi Kerupuk Ubi Kayu}

Besarnya produksi yang di hasilkan dalam suatu usaha kerupuk ubi kayu akan mempengaruhi jumlah penggunaan fungsi dan sarana produksi. Pengalokasian faktor dan sarana produksi yang efektif dan efisien akan mempengaruhi banyaknya jumlah produksi.

Masalah utama yang terjadi dalam pengolahan usaha kerupuk ubi kayu, adalah ketersedian bahan baku, karna tidak terpenuhinya kebutuhan ubi kayu di Desa Pulau Aro, kualitas ubi juga menjadi pertimbangan bagi produsen untuk membeli ubi kayu dari Sumatra Barat. Harga beli ubi kayu dari Desa Pulau Aro dan Sumatra Barat seharga Rp.2.500/Kg.

\section{Jumlah Produksi Kerupuk Ubi Kayu}

Produksi yang diperoleh pengusaha kerupuk ubi kayu sampel mulai dua kali per minggu, dalam perhitungan hasil yang terima dihitung dalam bentuk berat kerupuk ubi produksi dengan satuan kilogram per produksi. Produksi yang tinggi tanpa diimbangi dengan harga yang layak maka tidak akan mendapatkan pendapatan yang optimal. Lebih jelasnya dapat dilihat pada Tabel 1.

Tabel 1. Distribusi Rata-rata Produksi dan Penerimaan Kotor Pada Usaha Agroindustri Kerupuk Ubi kayu di

\begin{tabular}{|c|c|c|c|}
\hline No & Uraian & Satuan & Jumlah \\
\hline \multirow{4}{*}{1} & Produksi & & \\
\hline & a. Hari & $\mathrm{Kg}$ & 7 \\
\hline & b. Minggu & $\mathrm{Kg}$ & 29 \\
\hline & c. Bulan & $\mathrm{Kg}$ & 145 \\
\hline 2 & Harga & $\mathrm{Rp}$ & 22.000,- \\
\hline 3 & $\begin{array}{l}\text { Penerimaan Kotor } \\
\text { a. Hari }\end{array}$ & $\mathrm{Rp}$ & 159.757,- \\
\hline
\end{tabular}
Desa Pulau Aro 


\begin{tabular}{|c|c|c|c|}
\hline No & Uraian & Satuan & Jumlah \\
\hline & b. Minggu & $\mathrm{Rp}$ & 639.027,- \\
\hline & c. Bulan & $\mathrm{Rp}$ & 3.195.133,- \\
\hline
\end{tabular}

Pada Tabel 1 dapat dilihat produksi kerupuk ubi kayu rata-rata per hari $7 \mathrm{~kg}$ dan per minggu yang diperoleh pengusaha kerupuk ubi kayu adalah $29 \mathrm{~kg}$ sedangkan perbulan $145 \mathrm{~kg}$, dengan harga rata-rata $\mathrm{Rp}$. $22.000,-/ \mathrm{kg}$. Sedangkan pendapatan kotor rata-rata pengusaha kerupuk ubi kayu per hari adalah sebesar Rp. 159.757,- dan perminggu yang diperoleh oleh pengusaha kerupuk ubi kayu adalah Rp. 639.027,- dan pendapatan rata-rata perbulan adalah Rp. 3.195.133,-.

Untuk bahan pengolahan kerupuk ubi kayu hanya membutuhkan garam dan minyak goreng. Garam dan minyak goreng sangat mudah diperoleh dan harga yang terjangkau. Untuk proses perebusan, pengusaha mengandalkan kayu bakar yang dicari sendiri.

\section{Harga Penjualan}

Pelaku pasar teratas atau pedagang pengumpul menentukan harga kepada pengusaha kerupuk ubi kayu. Proses penentuan harga ini menyebabkan pengusaha kerupuk ubi kayu berada pada posisi terbawah sehingga paling lemah dalam menentukan harga. Bahwa harga ditentukan atas dasar kekuatan permintaan dan penawaran antara pedagang dan produsen ataupun antara konsumen dengan pedagang. Penetapan harga yang lebih tinggi akan merangsang kegiatan produksi, sebaliknya jika terjadi penurunan harga akan menurunkan produksi bahkan menghentikan produksi.

Adapun harga jual kerupuk ubi kayu ditingkat pengusaha kerupuk ubi kayu berkisar antara Rp. 20.000 22.000,- dan harga jual kerupuk ubi kayu ditingkat pedagang pengumpul berkisar antara Rp. 23.000 25.000 .

\section{Analisis Pemasaran Bahan Olahan Karet}

\section{Saluran Pemasaran}

Saluran pemasaran merupakan jalur dari lembaga-lembaga pemasaran yang mempunyai kegiatan menyalurkan barang dari produsen ke konsumen. Adanya pola saluran pemasaran ini akan mempengaruhi besar kecilnya biaya pemasaran serta besar kecilnya harga yang dibayar oleh konsumen. Pola saluran pemasaran agroindustri kerupuk ubi kayu dapat diketahui dengan cara mengikuti arus pemasaran kerupuk ubi kayu mulai dari pengusaha agro industri kerupuk ubi kayu sampai pedagang pengumpul hinga sampai ke konsumen.

Saluran pemasaran kerupuk ubi kayu di Desa Pualau Aro ada dua saluran yaitu saluran I pengusaha kerupuk ubi kayu menjual langsung dari rumah, konsumen langsung datang membeli kerupuk ubi kayau dalam bentuk mentah ke rumah tempat produksi kerupuk ubi kayu.

Saluran pemasaran II pengusaha kerupuk ubi kayu menjual kerupuk ubi kayu dalam bentuk mentah ke pasar tradisional yang terdekat ke pedagang pengumpul dan pedagang pengumpul jual langsung ke konsumen dalam bentuk mentah dan masak.

Analisis pemasaran ini ditelusuri melalui saluran pemasaran kerupuk ubi kayu dalam bentuk mentah mulai dari pengusaha kerupuk ubi kayu ke pedagang pengumpul sampai pada konsumen. Ini maksudnya untuk mengkaji mekanisme arus barang dan masalah yang dihadapi oleh berbagai pihak yang terlibat. Untuk lebih jelasnya mengenai rantai pemasaran dapat dilihat pada Gambar 1.

\section{Saluran Pemasaran I}

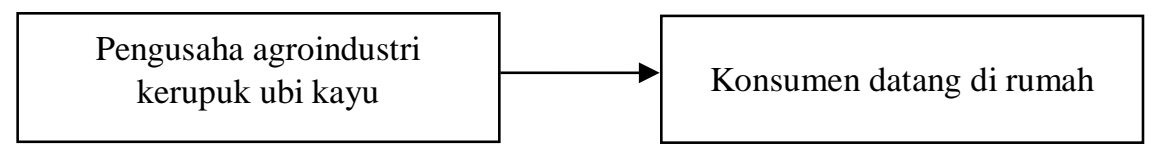

Saluran Pemasaran II

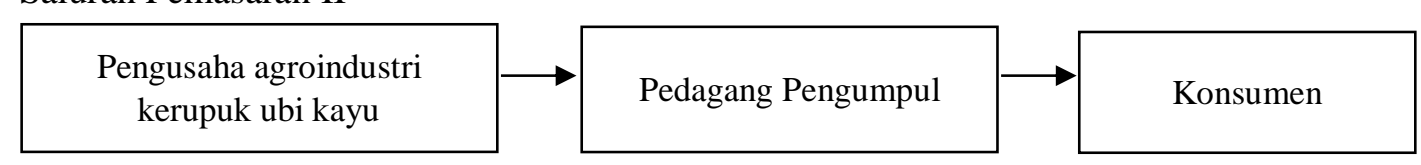

Gambar. 1 Rantai Pemasaran Kerupuk Ubi Kayu dari Pengusaha Sampai ke Konsumen 
Kerupuk ubi kayu dipasarkan melalui dua saluran, yaitu saluran pemasaran I kerupuk ubi kayu dipasarkan lasung dirumah, konsumen yang langsung datang kerumah membeli kerupuk ubi kayu dalam bentuk mentah, hal ini di lakukan agar dari hasil produksi ubi kayau supaya cepat terjual dan mendapat keuntungan cepat. Saluran Pemasaran II kerupuk ubi kayu dalam bentuk mentah di pasarkan langsung ke tempat pasar-pasar tradisional yang terdekat ke pedagang pengumpul yang ada di pasar dan pedagang pengumpul jual kekonsumen dalam bentuk mentah dan sudah masak.

\section{Lembaga Pemasaran}

Lembaga pemasaran merupakan badan-badan yang menyelenggarakan kegiatan pemasaran, dimana barangbarang yang bergerak dari pihak produsen sampai pada pihak konsumen. Lembaga pemasaran yang terlibat dalam usaha kerupuk ubi kayu di daerah penelitian pada saluran pemasara I terdiri dari pengusaha kerupuk ubi kayu dan konsumen, karena pengusaha jual langsung kerupuk ubinya kepada konsumen yang langsung datang ke rumah dalam bentuk kerupuk mentah. Saluran pemasaran II terdiri dari pengusaha kerupuk ubi kayu dan pedagang pengumpul serta sampai kekonsumen. Pedagang pengumpul berperan dalam membeli kerupuk ubi kayu dari pengusaha kerupuk ubi kayu, kemudian pedagang pengumpul menjual kembali ke pada kosumen dalam bentuk mentah maupun yang sudah di masak. Berikut ini akan dijelaskan tentang lembaga-lembaga pemasaran kerupuk ubi kayu tersebut:

\section{Pengusaha kerupuk ubi kayu}

Pengusaha kerupuk ubi kayu merupakan produsen yang memproduksi dan menjual kerupuk ubi kayu dalam bentuk mentah, yaitu pengusaha kerupuk ubi kayu yang menjual kerupuk ubi kayu baik di jual langsung dirumah maupun di jual di pasar-pasar tradisional dan menjual kerupuk ubi kayunya pada pedagang pengumpul. Pengusaha kerupuk ubi kayu membuat setiap hari kerupuk ubi kecuali hari rabu dan minggu karena hari kedua ini merupakan hari pasar. Dari hasil penelitian harga yang ditawarkan oleh pedagang pengumpul ke pengusaha kerupuk ubi kayu berkisar antara Rp.20.000,- sampai Rp. 22,000,- per kilonya.

\section{Pedagang Pengumpul}

Pedagang pengumpul adalah pedagang yang membeli langsung kerupuk ubi kayu pada pengusaha kerupuk ubi kayu di pasar yang dianggap strategis untuk menunggu, menawar dan membeli langsung kerupuk ubi kayu dari pengusaha kerupuk ubi kayu di wilayah tersebut. Dari hasil penelitian harga yang ditawarkan oleh konsumen ke pedagang pengumpul berkisar antara Rp. 23.000,- sampai Rp. 25.000,- per kilonya dalam bentuk mentah.

\section{Fungsi Lembaga Pemasaran Kerupuk Ubi Kayu}

Lembaga pemasaran berperan dalam menyalurkan kerupuk ubi kayu yang di produksi pengusaha kerupuk ubi kayu sehingga sampai ke konsumen. Tugas lembaga pemasaran adalah menjalankan fungsi-fungsi pemasaran.

Fungsi pemasaran bukan hanya sekedar menjual barang, melainkan harus mencakup segala fungsi dan kegiatan yang sangat luas. Pemasaran merupakan kegiatan ekonomi yang mencakup pendistribusian barang dan jasa mulai dari produsen hingga ke konsumen. Fungsi pemasaran berkerja melalui lembaga pemasaran atau struktur pemasaran, atau dengan kata lain pemasaran ini harus ditampung dan dipecahkan oleh produsen dan mata rantai saluran barang-barangnya, dan lembaga lain yang terlibat dalam proses pemasaran.

Fungsi-fungsi pemasaran yang dilakukan berdasarkan hasil penelitian maka fungsi pemasaran kerupuk ubi kayu yang ada di Desa Pulau Aro adalah sebagai berikut:

\section{Fungsi Penjualan}

Fungsi penjualan yang dilakukan oleh pengusaha kerupuk ubi kayu yaitu dengan menjual langsung di rumah yaitu konsumen lansung datang ke rumah, dan juga membawa kerupuk ubi kayu mereka ke pasar tradisional yang terdekat yang umum digunakan transaksi jual beli. Adapun kerupuk ubi kayu yang dijual pengusaha kerupuk ubi kayu adalah jenis kerupuk mentah. Ditempat penjualan sudah menunggu para pedagang pengumpul yang akan membeli kerupuk ubi kayu, tawar menawar pun terjadi antara pengusaha kerupuk ubi kayu dan pedagang pengumpul untuk menentukan harga jual yang disepakati nanti secara bersama-sama. Setelah harga disepakati barulah terjadi proses jual beli antara pengusaha kerupuk ubi kayu dan pedagang. Proses yang sama juga terjadi antara pedagang pengumpul dan kosumen, dimana pedagang pengumpul sebagai pihak penjual dan konsumen sebagai pihak pembeli. Harga pada tahap ini ditetapkan atas kesepakatan bersama. 


\section{Fungsi Pembelian}

Fungsi pembelian yaitu suatu perpindahan kerupuk ubi kayu dari pengusaha kerupuk ubi kayu, pedagang sampai ke konsumen melalui proses transaksi. Dalam hal ini lembaga pemasaran yaitu pedagang pengumpul membeli kerupuk ubi kayu kepada pengusaha kerupuk ubi kayu dan pedagang pengumpul untuk kemudian dijual kembali ke konsumen akhir.

Pembelian merupakan suatu fungsi yang bersangkutan dengan perpindahan atau pemilikan barang yang dimaksudkan persedian produksi ataupun untuk keperluan mencukupi kebutuhan. Sedangkan penjualan merupakan kegiatan-kegiatan untuk mencari atau mengusahakan agar barang-barang yang telah dimiliki mendapatkan permintaan pasar yang cukup banyak, terutama mengenai kuantitas dan harga yang cukup menguntungkan.

Pembelian dilakukan langsung oleh pedagang pengumpul kepada pengusaha kerupuk ubi kayu. Biasanya pedagang pengumpul telah mempunyai pengusaha kerupuk ubi kayu sebagai langganannya, maka pedagang tersebut melakukan pembelian kerupuk ubi dua kali dalam seminggu yaitu hari pasar rabu dan minggu.

\section{Fungsi Pengangkutan}

Fungsi pengangkutan yaitu bergeraknya atau pindahnya barang kerupuk ubi kayu dari tempat pengusaha kerupuk ubi kayu ke pasar tempat penjualan, pedagang penggumpul menuju tempat penjualan dimana kerupuk ubi kayu tersebut akan di jual kembali ke konsumen dalam bentuk mentah dan masak yang sudah di goreng, yang bertujuan untuk menyampaikan barang atau jasa di daerah konsumen sesuai dengan jumlah dan mutunya. Fungsi ini dapat dilihat dalam proses menyampaikan produk kerupuk ubi kayu yang dijual pengusaha ke pedagang akhirnya sampai ke konsumen.

Pengakutan merupakan kegiatan pemindahan suatu barang dari pengusaha kerupuk ubi kayu ke pedagang pengumpul dan ke konsumen.

\section{Fungsi Penyimpanan}

Fungsi penyimpanan yaitu menyimpan kerupuk ubi kayu selama jangka waktu tertentu dan untuk dijual kembali. Fungsi ini tidak banyak dilakukan oleh pedagang, kecuali pengusaha kerupuk ubi kayu yang melakukannya menjelang kerupuk ubi mereka terjual. Produksi kerupuk ubi kayu dari pengusaha dapat dijual langsung pada hari pengolahan atau menunggu satu hari kemudian pada hari pasar lokal atau Desa. Penyimpanan kerupuk ubi kayu bagi pengusaha bertujuan untuk mengumpulkan hasil dari pembuatan setiap hari sehinga nanti dalam penjualan bisa sekali banyak dan bisa efisien biaya, ada pun penjualan di lakukan dua kali seminggu yaitu pada hari pasar rabu dan minggu.

\section{Standarisasi}

Standarisasi merupakan fungsi penting dalam proses pemasaran dan begitu juga dalam pemasaran kerupuk ubi kayu. Tetapi standarisasi dalam kerupuk ubi kayu tidak ada disini hanya standarisasi dari bentuk kerupuk ubi sendiri, apabila kerupuk ubinya bersih maka konsumen maupun pedagang pengumpul akan membeli kerupuk ubi terseabut. Adapun fungsi standarisasi dari konsumen dia hanya melihat bentuk dan kebersihan kerupuk dari pedagang pengumpul begitujuga pedagang pengumpul ke produsen pengusaha kerupuk ubi kayu. Kerupuk ubi kayu yang bersih dan berwarna putih ke kuning-kuningan dan betuk bulat serta bersih dari kotoran. Untuk menentukan standar tersebut pedagang tidak menggunakan alat, tetapi berdasarkan pengalaman. Adapun harga yang ditawarkan oleh pedagang pengusaha kerupuk ubi kayu berkisar antara Rp. 20.000,- sampai Rp. 22.000,- per kilonya.

\section{Fungsi Pembiayaan}

Fungsi pembiayaan adalah biaya yang dikeluarkan dalam proses pemasaran kerupuk ubi kayu meliputi biaya transportasi, penyusutan dan sebagainya. Setiap lembaga pemasaran yang terlibat dalam pemasaran kerupuk ubi kayu akan menanggung biaya tersebut, dan bahkan pedagang pengumpul jual langsung ke konsumen. Besarnya biaya transportasi sangat tergantung pada jarak tempuh, biaya ditentukan oleh penjualan atau pembelian dan biaya penyusutan tergantung pada kerupuk ubi yang dibeli dan dijual. Besar kecilnya biaya yang dikeluarkan dalam pemasaran kerupuk ubi kayu akan berdampak langsung pada harga beli ditingkat pengusaha kerupuk ubi kayu. Ini berarti pengusaha kerupuk ubi kayu selalu menangung resiko terhadap kenaikan biaya pemasaran yang dialami pedagang. 


\section{Fungsi Penanggung Resiko}

Fungsi penanggung resiko merupakan sebagai ketidak pastian dalam jual beli yaitu hubungannya dengan ongkos, kerugian atau kerusakan kerupuk ubi kayu selama pemasaran berlangsung, adapun fungsi penagung resiko terjadi saat kerupuk ubi kayu tidak terjual.

Resiko merupakan suatu tantangan yang sering dihadapi mulai dari pengusaha kerupuk ubi kayu sampai ke konsumen akhir. Resiko yang dihadapi pengusaha kerupuk ubi kayu hanyalah resiko harga yang berfluktuasi, sedangkan resiko yang dihadapi pedagang selain fluktuasi harga, kerusakan pada kerupuk ubi kayu kadang-kadang juga menyebabkan pedagang mengalami kerugian.

\section{Fungsi Informasi Pasar}

Fungsi informasi pasar meliputi kegiatan pengumpulan informasi pasar serta menafsirkan data informasi tersebut. Untuk membentuk sistem pemasaran yang baik, informasi pasar ini sangat diperlukan. Efisiensi pemasaaran tidak dapat dicapai dalam keadaan menguntungkan tanpa informasi pasar (Hanafiah dan Saifuddin, 1986).

Informasi pasar sangat penting dan perlu didapatkan baik oleh pengusaha maupun pedagang, karena tingkat harga yang berlaku pada saat terjadi proses jual beli akan langsung menentukan tingkat penerimaan pengusaha atau keuntungan pedagang. Dalam pemasaran kerupuk ubi kayu, harga ditentukan oleh kelangkaan bahan baku, karena bahan baku di ambil dari luar kuansing apabila di pasar taluk habis maka beli ubi yang di datang dari Sumbar dengan hargha lebih mahal di bandingkan dari Taluk dan harga ditingkat pedagang pengumpul.

Fungsi informasi pasar adalah suatu tindakan-tindakan lapangan yang mencakup pengumpulan informasi, komunikasi, penafsiran dan pengambilan keputusan sesuai dengan rencana dan kebijakan pedagang yang bersangkutan. Fungsi informasi pasar dilakukan terutama oleh pedagang, hal ini dilakukan untuk mengetahui berapa kebutuhan kerupuk ubi kayu yang harus dibeli dengan jumlah permintaan oleh konsumen.

\section{Biaya Pemasaran}

Biaya pemasaran merupakan biaya yang dikeluarkan selama proses pemasaran berlangsung, mulai dari produk lepas dari tangan pengusaha kerupuk ubi kayu hingga diterima konsumen. Dari batasan ini sudah dapat dibayangkan bahwa biaya dapat besar atau kecil tergantung pada panjang pendeknya jalur pemasaran dan peran fungsi tata niaga.

Kegiatan pemasaran seringkali melibatkan biaya, sebab dalam proses tersebut produk akan mengalami perlakuan yang dapat menambah nilai produk tersebut. Besarnya biaya yang dikeluarkan selama proses pemasaran akan dibebankan kepada konsumen.

Pada saluran pemasaran I, yang terlibat adalah pengusaha kerupuk ubi kayu dan konsumen akhir. Pengusaha kerupuk ubi kayu tidak ada mengeluarkan biaya-biaya pemasaran kareana hasil produksi kerupuk ubi kayu langsung di jual di rumah. Jadi tidak ada biaya pemasaran yang di keluarkan sehinga keuntungan yang didapat cukup tinggi. Biasa efisien pemasaran yang di peroleh adalah sebesar $0 \%$, ini di karenakan tidak ada biaya pemasaran yang di keluarkan sehingga dapat di katakana saluran pemasaran I efisien.

Untuk melihat saluran pemasaran II yaitu dalam hal memasarkan kerupuk ubi kayu, pengusaha kerupuk ubi kayu pengusaha hanya mengeluarkan biaya transportasi dari rumah kepasar sebesar Rp. 2000,- adapun jarak rumah dengan pasar berkisar $3 \mathrm{~km}$ dan nada juga kerupuk ubi kayu dijemput langsung oleh pedagang pengumpul, sedangkan pedagang pengumpul mengeluarkan biaya operasional seperti biaya transportasi, biaya beli plastik rata-rata sebesar Rp. 23.000,-/bulan atau sebesar Rp. 260,-/kg, untuk lebih jelasnya dapat dilihat pada Tabel. 2 di bawah ini.

Tabel 2. Analisis Pemasaran Kerupuk Ubi Kayu Di Desa Pulau Aro.

\begin{tabular}{clcc}
\hline \multirow{2}{*}{ No } & \multicolumn{1}{c}{ Uraian } & \multicolumn{2}{c}{ Perminggu } \\
& \multicolumn{1}{c}{ Biaya (Rp/Kg) } & Share (\%) \\
\hline A & Pengusaha kerupuk Ubi & 22 & 90 \\
1 & Harga jual & & \\
B & Pedagang Pengumpul & 21.4 \\
1 & Harga Beli & 260 \\
2 & Biaya Operasional Pemasaran & 2958 \\
3 & Keuntungan & 3000 & 10 \\
4 & Margin & 24 & \\
5 & Harga Jual & 0,09 &
\end{tabular}




\begin{tabular}{|c|c|c|c|}
\hline \multirow{2}{*}{ No } & \multirow{2}{*}{ Uraian } & \multicolumn{2}{|c|}{ Perminggu } \\
\hline & & Biaya $(\mathbf{R p} / \mathbf{K g})$ & Share $(\%)$ \\
\hline D & Harga Konsumen & 24.4 & 100 \\
\hline $\mathbf{E}$ & Total Biaya Operasional Pemasaran & 260 & \\
\hline $\mathbf{F}$ & Margin Pemasaran & 2.4 & \\
\hline G & Efisiensi Pemasaran & 1,07 & \\
\hline
\end{tabular}

Pada tabel 2 menunjukkan pengusaha kerupuk ubi kayu rata-rata menerima harga Rp.22.000,-/kg atau bagian harga yang di terima pengusaha kerupuk ubi kayu adalah 90\% di harga tingkat konsumen akhir. Hal ini berarti harga yang di terima pengusaha kerupuk ubi kayu tinggi sehingga pengusaha kerupuk ubi kayu tidak dirugikan. Biaya pemasaran pada saluran pemasaran II ditanggung oleh pedagang pengecer. Biaya pemasaran yang ditanggung oleh pedagang pengumpul adalah biaya operasional seperti, biaya transportasi, biaya plastik, dan adapun biaya rata-rata sebesar Rp. 23.000,-- atau sebesar Rp. 260,-.

Biaya pemasaran kerupuk ubi kayu dalam bentuk biaya operasional sebesar Rp. 260,- biaya pemasaran yang dikeluarkan oleh pedagang pengumpul, lebih jelasnya dapat dilihat pada Tabel. 2.

\section{Margin Pemasaran}

Margin pemasaran adalah selisih antara harga ditingkat produsen dengan harga yang dibayar konsumen. Margin pemasaran kerupuk ubi kayu di peroleh sebesar Rp. 2.400,-/kg. Margin pemasaran saluran pemasaran II yang dikelaurkan oleh pedagang pengumpul sebesar Rp. 3.000,-/kg dengan harga jual 24.400,$/ \mathrm{kg}$ atau bagian harga yang diterima pedagang pengumpul dalam menjual kerupuk ubi kayu adalah $10 \%$ di harga tingkat konsumen akhir. Ini disebabkan karena lembaga pemasaran yang terlibat dalam saluran pemasaran II ini hanya pedagang pengecer. Nilai efisiesi pemasaran pada saluran pemasaran II di peroleh sebesar 0,09 dan dari perhitungan hematensi pemasaran terseabut dapat dilihat keuntungan yang diperoleh lebih besar dari pada mencakup biaya yang dikeluarkan, maka dapat dikatakan sistem pemasaran pada saluran pemasaran II efisien.

\section{Keuntungan Pemasaran}

Setiap fungsi pemasaran yang di lakukan oleh tiap pelaku usaha tentunya menimbulkan biaya pemasaran yang berbeda-beda, perbedaan tersebut di tentukan oleh jarak lokasi penjualan dan pembelian, volume penjualan, modal usaha, dan bentuk barang yang dijual. Disamping itu, keuntungan tiap pelaku pemasaran dapat di ketahui setelah mengurangi penerimaan yang di peroleh dari hasil penjualan kerupuk ubi kayu dengan biaya usaha yang dikeluarkan selama proses pemasaran.

Keuntungan yang diperoleh oleh pedagang pengumpul sebesar Rp. 2.958,-/kg. Lebih jelasnya dapat dilihat pada Tabel. 2.

\section{Efisiensi Pemasaran}

Pemasaran yang efisien berarti mampu mengalirkan produk dengan biaya yang seminimal mungkin. Tingkat harga dan keuntungan yang wajar dan adil serta penjualannya dapat dilakukan dengan tepat. Efisiensi pemasaran secara keseluruhan tergantung pada efisiensi tiap-tiap saluran pemasaran yang terlibat didalamnya. Suatu saluran pemasaran dianggap efisien secara ekonomis apabila masing-masing saluran pemasaran mempunyai nilai persentase marjin pemasaran yang rendah dan nilai farmer's share yang tinggi. Nilai persentase marjin pemasaran secara tidak langsung tergantung pada panjang pendeknya saluran pemasaran, sedangkan panjang pendeknya saluran pemasaran dipengaruhi oleh banyaknya lembaga pemasaran yang terlibat di dalam suatu saluran pemasaran. Hal ini dikarenakan adanya biaya yang harus dikeluarkan dan keuntungan yang diharapkan. Semakin banyak lembaga pemasaran yang terlibat dalam pemasaran suatu produk atau semakin panjang saluran pemasaran, maka nilai persentase marjin pemasarannya semakin besar.

Berdasarkan hasil penelitian efisiensi pemasaran kerupuk ubi kayu di Desa Pulau Aro dapat dilakukan dengan membandingkan total biaya pemasaran dengan total nilai produk. Analisis terhadap dua kali saluran yang ada di desa Pulau Aro dapat dilihat pada Tabel 3. Dari Tabel 3 dapat dilihat nilai efisieni pemasaran pada saluran pemasaran I adalah $0 \%$, lebih kecil nilai efisiensi pemasaran pada saluran pemasaran II adalah 1,07\%. Hal ini berarti saluran pemasaran I lebih efisien dari pada saluran pemasaran II. Pada saluran pemasaran I marjin pemasarannya adalah Rp. 0,- sedangkan pada saluran pemasaran II melibatkan satu 
lembaga pemasaran dengan marjin pemasaran Rp.2.400,- hal ini menunjukan saluran pemasaran yang pendek lebih efisien sebagai saluran pemasaran.

Tabel 3. Hasil Perhitungan Efisiensi Pemasaran Pada saluran Pemasaran Kerupuk Ubi Kayu di Desa Pulau Aro

\begin{tabular}{clc}
\multicolumn{2}{c}{ Aro } & \\
\hline No & \multicolumn{1}{c}{ Saluran Pemasaran } & Efisiensi pemasaran \\
\hline 1 & Saluran Pemasaran I & $0 \%$ \\
2 & Saluran Pemasaran II & $1,07 \%$ \\
\hline
\end{tabular}

Hasil penelitian ini menunjukkan bahwa efisiensi pemasaran kerupuk ubi kayu di daerah penelitian adalah sebesar 1,07. Hal ini disebabkan karena dalam memasarkan kerupuk ubi kayu tidak mengeluarkan biaya yang terlalu besar, maka dapat dikatakan bahwa efisiensi pemasaran kerupuk ubi kayu di daerah penelitian sudah efisien, dimana setiap Rp. 100 nilai produk yang dipasarkan hanya memerlukan biaya pemasaran sebesar Rp. 1,07 dimana bila semakin rendah ratio total biaya dengan total nilai produk maka sistem pemasaran semakin efisien dan sebaliknya apabila semakin tinggi ratio total biaya dengan total nilai produk maka sistem pemasaran tidak efisien. Dengan demikian pemasaran kerupuk ubi kayu di daerah penelitian sangat efisien.

\section{KESIMPULAN}

Adapun hasil penelitian dapat disimpulkan sebagai berikut:

1. Produksi kerupuk ubi kayu rata-rata per hari $7 \mathrm{~kg}$ dan per minggu $29 \mathrm{~kg}$ perbulan $145 \mathrm{~kg}$, dengan harga rata-rata Rp. 22.000,-/kg. Pendapatan kotor rata-rata pengusaha kerupuk ubi kayu per hari adalah sebesar Rp. 159.757,- dan perminggu adalah Rp. 639.027,- dan perbulan adalah Rp. 3.195.133,-.

2. Pada saluran pemasaran I, yang terlibat adalah pengusaha kerupuk ubi kayu dan konsumen akhir. Pengusaha kerupuk ubi kayu tidak ada mengeluarkan biaya-biaya pemasaran kareana hasil produksi kerupuk ubi kayu langsung di jual di rumah. Saluran pemasaran II yaitu dalam hal memasarkan kerupuk ubi kayu, pengusaha kerupuk ubi kayu, hanya mengeluarkan biaya transportasi dari rumah kepasar sebesar Rp. 2000,- adapun jarak rumah dengan pasar berkisar $3 \mathrm{~km}$, dan nada juga kerupuk ubi kayu dijemput langsung oleh pedagang pengumpul, sedangkan pedagang pengumpul mengeluarkan biaya operasional rata-rata sebesar Rp. 23.000,-/bulan atau sebesar Rp. 260,-/kg,

3. Margin pemasaran kerupuk ubi kayu di peroleh sebesar Rp. 2.400,-/kg. Margin pemasaran saluran pemasaran II yang dikelaurkan oleh pedagang pengumpul sebesar Rp. 3.000,-/kg dengan harga jual $24.400,-/ \mathrm{kg}$, efisieni pemasaran pada saluran pemasaran I adalah $0 \%$, lebih kecil nilai efisiensi pemasaran pada saluran pemasaran II adalah 1,07\%. Hal ini berarti saluran pemasaran I lebih efisien dari pada saluran pemasaran II. Pada saluran pemasaran I marjin pemasarannya adalah Rp. 0,--

\section{Saran}

Dari hasil pembahasan dari penelitian ini maka dapat disarankan hal-hal sebagai berikut:

a. Harga jual pengusaha kerupuk ubi kayu dapat dipertahankan dan ditingkatkan dengan perbaikan kualitas kerupuk ubi kayu.

b. Perlu adanya suatu lembaga penunjang, misalnya koperasi untuk mengurangi rantai pemasaran sehingga petani dapat bebas menjual kepada pedagang yang dapat menawarkan harga yang lebih tinggi. Dengan demikian dapat menimbulkan persaingan antara pedagang. Konsekuensi adanya koperasi ini, pengusaha diharapkan menjadi anggota dan koperasi mampu memenuhi kebutuhan para angotanya bahkan diluar anggota.

\section{DAFTAR PUSTAKA}

Baharsjah, S. 1992. Pengembangan Agribisnis dan Agroindustri di Indonesia. Jakarta: Departemen Pertanian.

Dinas Tanaman Pangan. 2015. Kabupaten Kuantan Singingi dalam Angka 2016. Kuantan Singingi.

Diskopindag. 2017. Data Perkembangan Usaha Mikro, Kecil dan Menengah Kabupaten Kuantan Singingi Per-30 Oktober 2017. Teluk Kuantan.

Hanani, N., J.T. Ibrahim., dan M. Purnomo. 2003. Strategi Pengembangan Pertanian: Sebuah Pemikiran Baru. Jakarta: Lappera Pustaka Utama. 
Hanafiah dan Syaifudin, 1986. Tata Niaga Hasil Perikanan. Jakarta: Universitas Indonesia Press.

Soekartawi. 1993. Prinsip Dasar Manajemen Pemasaran Hasil-Hasil Pertanian Teori dan Aplikasinya. Jakarta: Raja Grafindo Perkasa.

Soekartawi. 2000. Pengantar Agroindustri. Jakarta: PT Raja Grafindo Persada.

Soekartawi. 2002. Prinsip Dasar Ekonomi Pertanian Teori dan Aplikasinya. Jakarta: Raja Grafindo Persada. 